\title{
Needle in a haystack: involvement of the copepod Paracartia grani in the life-cycle of the oyster pathogen Marteilia refringens
}

\author{
C. AUDEMARD ${ }^{1}$, F. LE ROUX ${ }^{1}$, A. BARNAUD ${ }^{1}$, C. COLLINS ${ }^{1}$, B. SAUTOUR ${ }^{2}$, \\ P-G. SAURIAU ${ }^{3}$, X. DE MONTAUDOUIN², C. COUSTAU ${ }^{4}$, C. COMBES ${ }^{4}$ \\ and F. BERTHE ${ }^{1 *}$ \\ 'Laboratoire Génétique et Pathologie, IFREMER, BP 133, 17390 La Tremblade, France \\ ${ }^{2}$ Laboratoire d'Océanographie Biologique, UMR 5805 - Université Bordeaux I-CNRS, 2, rue du Professeur Yolyet, \\ 33120 Arcachon, France \\ "Centre de Recherche en Ecologie Marine et Aquaculture, L'Honneau, B.P.5, 17137 L'Houmeau, France \\ ${ }^{4}$ Laboratoire de Biologie Animale, CNRS UMR 5555, CBETM, Université de Perpignan, 66860 Perpignan, France
}

(Received 10 \%uly 2001 ; revised 19 September 2001 ; accepted 26 September 2001)

\begin{abstract}
SUM MARY
Marteilia refringens is a major pathogen of the European flat oyster, Ostrea edulis Linnaeus. Since its description, the lifecycle of this protozoan parasite has eluded discovery. Attempts to infect oysters experimentally have been unsuccessful and led to the hypothesis of a complex life-cycle involving several hosts. Knowledge of this life-cycle is of central importance in order to manage oyster disease. However, the exploration of $M$. refringens life-cycle has been previously limited by the detection tools available and the tremendous number of species to be screened in enzootic areas. In this study, these two restrictions were circumvented by the use of both molecular detection tools and a mesocosm with low biodiversity. Screening of the entire fauna of the pond for $M$. refringers DNA was systematically undertaken using PCR. Here, we show that the copepod Paracartia (Acartia) grani is a host of $M$. refringens. Not only was DNA of $M$. refringens consistently detected in $P$. grani but also the presence of the parasite in the ovarian tissues was demonstrated using in situ hybridization. Finally, successful experimental transmissions provided evidence that $P$. grani can be infected from infected flat oysters.
\end{abstract}

Key words: Marteilia refringens, Ostrea edulis, Paracartia grani, PCR, in situ hybridization, experimental transmission.

\section{INTRODUCTION}

Marteilia refringens (Grizel et al. 1974), a major pathogen of the European flat oyster, Ostrea edulis Linnaeus, is responsible for important mortalities and economic losses in the oyster industry (Alderman, 1979; Figueras \& Montes, 1988). During the past 3 decades of biological investigation, emergence of control strategies has been impeded by a najor obstacle, which is elucidating the life-cycle of this protozoan parasite. Early field observations led authors to suspect the involvement of other host species in the transmission of $M$. refringens (Balouet, 1979; Balouet, Cahour \& Chastel, $1979 a$; Balouet et al. 1979b; Grizel, 1985; Lester, 1986). This hypothesis was further supported when authors repeatedly failed to infect healthy oysters with oyster-derived parasites after cohabitation, injection or feeding (Balouet, 1979; Balouet et al. 1979a; Berthe et al. 1998). Although extensive efforts were

* Corresponding author: Laboratoire Génétique et Pathologie, IFREMER, BP 133, F- 17390 La Tremblade. Tel: +3354636 9843. Fax: +33546363751 . E-mail address: fberthe $(a)$ ifremer.fr made to identify potential hosts, these studies were strongly impeded by the technical limits of histology, transmission electron microscopy and immunohistochemistry as screening tools, and complicated by the hundreds or thousands of species present in enzootic areas (Balouet el al. 1979b; Grizel, 1985).

In the present study, we circumvented the problem of species diversity by choosing particular natural oyster ponds, locally named 'claires', in the Marennes-Oléron Bay. Environmental characteristics of claires strongly limit the number of inhabiting species as compared with intertidal areas and oyster beds. Claires host less than 100 recognizable species (Reymond, 1991; Audemard et al. 2001), versus more than 1000 on open shores as Marennes-Oléron Bay (de Montaudouin \& Sauriau, 2000). In addition, we recently developed a PCR-based tool allowing the detection of Marleilia DNA. Based on the sequence of the small subunit ribosomal RNA gene of $M$. refringens, specific polymerase chain reaction primers and in situ hybridization probes were designed (Le Roux et al. 1999; Berthe et al. 2000). PCR and in situ hybridization represent powerful tools for the detection of the parasite in potential 
hosts, because they are sensitive, rapid and independent of both developmental stages of the parasite and location in host species (Mialhe et al. 1995). Here, we first used PCR to screen every species sampled in the claire ponds for the presence of $M$. refringens. When consistent detection of $M$. refringens was observed in a given species, presence of the parasite was assessed using in situ hybridization. Finally, experimental transmission of the parasite was performed to confirm involvement of the candidate species in the $M$. refringens life-cycle.

MATERIALS AND METHODS

\section{Study site}

Claires in the Marennes-Oléron Bay (S-W France) are ponds with natural bottoms traditionally used for growing oysters (Korringa, 1976). Ponds which were used in this study, were located on the East Coast of Ile d'Oléron in the central zone of the Bay (Audemard et al. 2001). Water temperatures ranged from $8^{\circ} \mathrm{C}$ in February to $25^{\circ} \mathrm{C}$ in summer. From May to late September, mean values were higher than the $17^{\circ} \mathrm{C}$ threshold necessary for infection of flat oysters by $M$. refringens ( $G$ rizel, 1985). Salinity ranged from 28 in spring (April) to 37 in summer (August). Species from the pond were sampled on a monthly or weekly basis for macrofauna, meiofauna, or zooplankton respectively (Audemard et al. 2001).

\section{Screening by PCR}

For each species sampled in the pond analysed individually or by batches in the case of small species, tissues were suspended in 10 volumes of extraction buffer ( $\mathrm{NaCl} 100 \mathrm{~mm}$, EDTA $25 \mathrm{~mm}, \mathrm{pH}$ $8, \operatorname{SDS} 0.5 \%)$ containing proteinase $\mathrm{K}(100 \mu \mathrm{g} / \mathrm{ml})$. Following an overnight incubation at $50^{\circ} \mathrm{C}$, DNA was extracted using a standard protocol involving phenol/chloroform, and precipitation with ethanol. PCR was performed as described by Le Roux $e t a l$. (1999), with 2 different primer pairs: one pair CS1/CAS1, was common to 50 eukaryotic species examined including Marteilia (universal primers) providing an internal control of amplification experiments. The other, SS2/SAS1, was specific for $M$. refringens $18 \mathrm{~S}$ rDNA (Berthe et al. 2000 ; Le Roux et al. 1999). PCR was performed in $50 \mu \mathrm{l}$ with $10 \mathrm{ng}$ of purified DNA mixed with $5 \mu \mathrm{l}$ of PCR buffer $10 \times$, $5 \mu \mathrm{l}$ of $25 \mathrm{~mm} \mathrm{MgCl}_{2}, 5 \mu 1$ of $2 \mathrm{~mm}$ of each dNTP, $0 \cdot 5 \mu l$ of each primer at $100 \mu \mathrm{M}$ and $0 \cdot 25 \mu 1$ (1 unit) of Taq DNA polymerase (Promega). Samples were overlaid with mineral oil, denatured for $5 \mathrm{~min}$ at $94{ }^{\circ} \mathrm{C}$ and amplified by 30 cycles: $1 \mathrm{~min}$ at $94^{\circ} \mathrm{C}$ for denaturation, $1 \mathrm{~min}$ at $55^{\circ} \mathrm{C}$ for primers annealing, and $1 \mathrm{~min}$ at $72^{\circ} \mathrm{C}$ for elongation in a thermal cycler apparatus (Appligene). Polymerization at $72^{\circ} \mathrm{C}$ was then extended for $10 \mathrm{~min}$ to ensure completion of the amplified products.

\section{In situ hybridization}

Animals were placed in Davidson's fixative AFA (10\% glycerine, $20 \%$ formalin, $30 \% 95^{\circ}$ ethanol, $30 \% \mathrm{H}_{2} \mathrm{O}, 10 \%$ glacial acetic acid) for at least $24 \mathrm{~h}$ and then embedded in paraffin. The sections were subsequently treated by conventional histological procedures. In situ hybridization was performed as described by Le Roux et al. (1999). Sections were treated with proteinase $\mathrm{K}(100 \mu \mathrm{g} / \mathrm{ml})$ in TE buffer $\left(50 \mathrm{mM}\right.$ Tris, $10 \mathrm{~mm}$ EDTA), at $37^{\circ} \mathrm{C}$ for $20 \mathrm{~min}$. Slides were dehydrated by immersion in an ethanol series and air dried. Sections were placed in $50 \mu \mathrm{l}$ of hybridization buffer $(4 \times \mathrm{SSC}, 50 \%$ formanide, $1 \times$ Denhardt's solution, $250 \mu \mathrm{g} / \mathrm{ml}$ yeast $t R N A$, dextran sulphate $10 \%$ ) containing $10 \mathrm{ng}$ of the labelled probe. Two probes were used: (1) the digoxigeninlabelled probe, called Smart 2 specific for $M$. refringens and (2) a host probe, labelled with digoxigenin by PCR with universal primers and host DNA as template to assess the quality and accessibility of targetted nucleic acid (Le Roux et al. 1999). Sections were covered with in situ plastic cover-slips and placed on a heating block at $95^{\circ} \mathrm{C}$ for $5 \mathrm{~min}$. Slides were then cooled on ice for $1 \mathrm{~min}$ before overnight hybridization at $42^{\circ} \mathrm{C}$ in a humid chamber. Sections were washed twice for $5 \mathrm{~min}$ in $2 \times \mathrm{SSC}$ at room temperature, and once for $10 \mathrm{~min}$ in $0.4 \times \mathrm{SSC}$ at $42^{\circ} \mathrm{C}$. The detection steps were performed according to the manufacturer's instructions (Dig nucleic acid detection kit, Boehringer Mannheim).

\section{Experimental infections}

Uninfected oysters. Uninfected oysters, Ostrea edulis L., originating from the laboratory hatchery, were kept under laboratory conditions. Oysters were 2 years old at the time of the experiment. In total 30 oysters were checked at the time of the experiment for absence of $M$. refringens by means of digestive gland imprints.

Infected oysters. A batch of uninfected oysters originating from the laboratory hatchery, were placed in claire ponds during summer 1999 which led to their infection by $M$. refringens. They were then placed in laboratory tanks at $12^{\circ} \mathrm{C}$ until the beginning of the experiment in summer 2000. At this temperature, the parasite does not develop further in its flat oyster host and is not released into the environment (Berthe et al. 1998). Oysters were 2 years old at the time of the experiment. $M$. refringens prevalence in these oysters was $87 \%$. Before the experiment, oyster shells were cleaned with a brush to remove epibionts.

Uninfected copepods. Uninfected copepods, Paracartia (Acartia) grani, were reared in the laboratory 
following previously described protocols (Guerrero \& Rodriguez, 1998). A batch of 50 of these copepods was checked for the absence of $M$. refringens by means of PCR, as described above.

Infected copepods. Infected copepods, P. grani from the claire pond, were sampled every 4 days from August to September 2000. In situ hybridization was performed to test the presence of the parasite in $P$. grami on different sampling dates. Copepods were rinsed in filtered sea water and were directly added in tanks containing uninfected oysters.

\section{Physical parameters of the experiments}

The experimental and control tanks contained $20 \mathrm{l}$ of filtered sea water. During the experiments, they were kept in the laboratory under natural photoperiod with temperature ranging from 22 to $28^{\circ} \mathrm{C}$. Algal food (Isochrysis galbana, Chaetoceros pumilum and Tetraselmis suecica) was produced in the laboratory and added every day to each tank. Water from the tanks was partially renewed every 4 days with filtered seawater.

Trial 1: Oyster to copepod transmission. The experiment started on the 24 July 2000 and lasted 25 days. This duration approximately corresponds to the longevity of an adult calanoid copepod stage.

Five infected flat oysters were placed on a $500 \mu \mathrm{m}$ mesh located in the upper part of the tank. The mesh minimized the effect of oyster filtration currents and allowed contact of $M$. refringens sporonts shed with oyster faeces with the copepods. Uninfected copepods were added to the tanks at the beginning of the experiment. Three replicates of the experiment were performed. During the experiment, copepod samples were preserved in Davidson fixative for further in situ hybridization. The control experiment was designed as described above, but included uninfected flat oysters also placed on a mesh. Three replicates were performed.

Trail 2: Copepod to oyster transmission. Thirty uninfected flat oysters were placed on mesh in tanks. Copepods from the claire pond were added every 4 days, from August to September 2000. On 9 sampling dates of $P$. grani from the claire pond used in this trial, $M$. refringens was detected 3 times (on the 28 August, 4 and 11 of September) with prevalences below $12 \%$. The experiment ended 1 month after the last copepods were added. At the end of the experiment, flat oysters were analysed by in situ hybridization. Three replicates were performed. The control consisted of tanks containing 30 uninfected flat oysters as described above, but no copepods were added. At the end of the experiment, oysters were analysed by in situ hybridization. Three replicates of the experiment were performed.

\section{RESULTS}

\section{Screening by PCR}

The results are given in Table 1 . For each species or taxon sampled in the claire pond, the number of individuals analysed is indicated in column 2. PCR was performed on individuals or groups of individuals with primers (column 3). The number of positive PCRs (assessing possible DNA amplification) is indicated in column 4. For each sample in which amplification had been obtained with CSI/ CAS1 primers, PCR was performed with SS2/SAS1 primers specific for $M$. refringens and the number of positive detections is indicated in column 5 .

Based on the PCR amplifications, 4 groups of species can be distinguished: the species showing $1 /$ no detection of $M$. refringens, $2 /$ very rare detection, 3 / consistent detection, or 4/ undetermined status (column 5).

Among the 62 taxa or species analysed by PCR, 36 taxa or species (Table 1) belonged to the first group (no detection) and 11 species belong to the second group (very rare detection). In the third group there were 2 species (the cnidarian Cereus pedunculatus and the copepod Paracartia grani), in which there was repeated detection. In the case of $C$. pedunculatus, $M$. refringens DNA was detected 48 times out of 273 . Regarding P.grani, $M$. refringens DNA was detected in 5 batches out of 6 . The last group consisted of 13 species where no DNA amplification had been obtained by PCR, when performed with universal primers.

\section{In situ hybridization}

Given the consistent detection of $M$. refringens DNA in $C$. pedunculatus and $P$. grani, in situ hybridization was performed with Smart 2 probe in order to localize the parasite in potential host tissues.

\section{Cereus pedunculatus}

No hybridization was observed with Smart 2 in the tissues of $70 \mathrm{C}$. pedunculatus analysed (result not shown), Quality and accessibility of targeted nucleic acid was assessed by controls.

\section{Paracartia grani}

Observations were made on copepodid (juveniles) and adult stages. Hybridization with Smart2 was observed within the tissues of $P$. grani. The parasite 
Table 1. Screening by PCR of the total fauna sampled in the claire pond model

(Results of the screening by PCR of species sampled in the claire pond. PCR was first performed with 'universal' primers (PCR CS1/CAS1) and, in the case of amplification, with SS2/SAS1 primers. 'A', Ascidia; 'An', Annelida; 'C', Crustacea; 'Ch', Chaetognatha; 'Cn', Cnidaria; 'E', Echinodermata; 'F', Pisces; 'I', Insecta; 'M', Mollusca; 'N', Nematoda; 'Ne', Nemertea; 'Pl', Platyhelminthes.)

\begin{tabular}{|c|c|c|c|c|c|}
\hline Genus species & $\begin{array}{l}\text { Number of } \\
\text { individuals } \\
\text { analysed }\end{array}$ & $\begin{array}{l}\text { Number of } \\
\text { PCRs using } \\
\text { CS1/CAS1 } \\
\text { primers }\end{array}$ & $\begin{array}{l}\text { Number of } \\
\text { positives with } \\
\text { CS1/CAS1 } \\
\text { primers }\end{array}$ & $\begin{array}{l}\text { Number of } \\
\text { Group PCRs } \\
\text { using SS } 2 / \mathrm{SAS} 1 \\
\text { primers }\end{array}$ & Group \\
\hline Microdeutopus grillotalpa (C) & 731 & 61 & 49 & $0 / 49$ & 1 \\
\hline Palae monetes varians (C) & 287 & 53 & 44 & $0 / 44$ & 1 \\
\hline Pomatochistus microps (F) & 250 & 44 & 42 & $0 / 42$ & 1 \\
\hline Orchestia gammarella (C) & 140 & 53 & 37 & $0 / 37$ & 1 \\
\hline Hediste diversicolor (An) & 496 & 117 & 28 & $0 / 28$ & 1 \\
\hline Gammarus insensibilis (C) & 146 & 29 & 27 & $0 / 27$ & 1 \\
\hline Paleomon serralus $(\mathrm{C})$ & 190 & 38 & 26 & $0 / 26$ & 1 \\
\hline Harpacticoïd spp. (C) & 862 & 17 & 15 & $0 / 15$ & 1 \\
\hline Corophinm achuresicum (C) & 334 & 16 & 15 & $0 / 15$ & 1 \\
\hline Notomastus latericens (An) & 133 & 15 & 15 & $0 / 15$ & 1 \\
\hline Melita palmata $(\mathrm{C})$ & 201 & 27 & 14 & $0 / 1$ & 1 \\
\hline Hydrobia ventrosa (M) & 462 & 16 & 12 & $0 / 12$ & 1 \\
\hline Decapod larvae (zoé I) (C) & 204 & 15 & 12 & $0 / 12$ & 1 \\
\hline Holothuria sp. (E) & 242 & 11 & 11 & $0 / 11$ & 1 \\
\hline Corophinm sp. (C) & 102 & 20 & 8 & $0 / 8$ & 1 \\
\hline Nematoda spp. (N) & 514 & 10 & 8 & $0 / 8$ & 1 \\
\hline Balanus improvisus (C) & 30 & 7 & 7 & $0 / 7$ & 1 \\
\hline Tubificoïdes benedeni (An) & 47 & 7 & 7 & $0 / 7$ & 1 \\
\hline Lencophytia bidentata (M) & 56 & 14 & 6 & $0 / 6$ & 1 \\
\hline Hydrobia ulvae (M) & 129 & 21 & 6 & $0 / 6$ & 1 \\
\hline Spionidae sp. (An) & 39 & 6 & 4 & $0 / 4$ & 1 \\
\hline Anguilla anguilla $(\mathrm{F})$ & 4 & 4 & 4 & $0 / 4$ & 1 \\
\hline Gastropod larvae (M) & 116 & 4 & 4 & $0 / 4$ & 1 \\
\hline Platyhelminth spp. (Pl) & 14 & 4 & 4 & $0 / 4$ & 1 \\
\hline Acartia discaudala (C) & 42 & 2 & 2 & $0 / 2$ & 1 \\
\hline Amphipholis squamata (E) & 7 & 2 & 2 & $0 / 2$ & 1 \\
\hline Chlamys varia (M) & 2 & 2 & 2 & $0 / 2$ & 1 \\
\hline Haliplanella laciae (Cin) & 2 & 2 & 2 & $0 / 2$ & 1 \\
\hline Nephlys humbergii (An) & 4 & 2 & 2 & $0 / 2$ & 1 \\
\hline Ascidian larva (A) & 14 & 2 & 1 & $0 / 1$ & 1 \\
\hline Polychaeta annelid larva $(\mathrm{An})$ & 49 & 2 & 1 & $0 / 1$ & 1 \\
\hline Acartia bifilosa (C) & 35 & 1 & 1 & $0 / 1$ & 1 \\
\hline Chaetognath sp. (Ch) & 9 & 1 & 1 & $0 / 1$ & 1 \\
\hline Pseudopolydora antennata (An) & 8 & 1 & 1 & $0 / 1$ & 1 \\
\hline Alkmaria romijni (An) & 349 & 16 & 1 & $0 / \hat{1}$ & 1 \\
\hline Abra temuis (M) & 32 & 5 & 1 & $0 / 1$ & 1 \\
\hline Molgula manhanttensis (A) & 167 & 116 & 112 & $1 / 112$ & 2 \\
\hline Lineus gisserensis $(\mathrm{Ne})$ & 118 & 35 & 24 & $4 / 24$ & 2 \\
\hline Decapod larvae (zoe II) (C) & 570 & 28 & 23 & $1 / 23$ & 2 \\
\hline Canuella perplexa (C) & 966 & 19 & 19 & $1 / 19$ & 2 \\
\hline Haminoea hydatis (M) & 161 & 24 & 15 & $1 / 15$ & 2 \\
\hline Juveniles of Pomatochistus microps (F) & 282 & 17 & 15 & $3 / 15$ & 2 \\
\hline Cyclopoid spp. (C) & 362 & 15 & 14 & $1 / 14$ & 2 \\
\hline Euterpina acutifrons (C) & 362 & 15 & 14 & $2 / 14$ & 2 \\
\hline Ostracod spp. (C) & 287 & 10 & 10 & $1 / 10$ & 2 \\
\hline Streblospio shrubsolii (An) & 44 & 8 & 6 & $1 / 6$ & 2 \\
\hline Abra segmentum (M) & 166 & 29 & 2 & $1 / 2$ & 2 \\
\hline Cereus pedunculatus (Cn) & 732 & 345 & 273 & $48 / 273$ & 3 \\
\hline Paracartia grani (C) & 285 & 8 & 6 & $5 / 6$ & 3 \\
\hline Corophinm volutator $(\mathrm{C})$ & 32 & 6 & 0 & ND & 4 \\
\hline Chironomus salinarius (I) & 30 & 3 & 0 & ND & 4 \\
\hline Praumus flexuosus (C) & 23 & 1 & 0 & ND & 4 \\
\hline Idothea chelipes (C) & 22 & 5 & 0 & ND & 4 \\
\hline Carcinns maenas (C) & 13 & 13 & 0 & ND & 4 \\
\hline Crangon crangon (C) & 11 & 6 & 0 & $\mathrm{ND}$ & 4 \\
\hline Isopod sp. (C) & 8 & 2 & 0 & ND & 4 \\
\hline Doris verrucosa $(\mathrm{M})$ & 5 & 5 & 0 & ND & 4 \\
\hline Eulalia veridis (An) & 3 & 1 & 0 & $\mathrm{ND}$ & 4 \\
\hline Cerastoderma edule (M) & 2 & 2 & 0 & ND & 4 \\
\hline Ephydridae sp. (I) & 1 & 1 & 0 & ND & 4 \\
\hline Facellina coronata (M) & 1 & 1 & 0 & $\mathrm{ND}$ & 4 \\
\hline Polydora ciliata (An) & 1 & 1 & 0 & ND & 4 \\
\hline
\end{tabular}




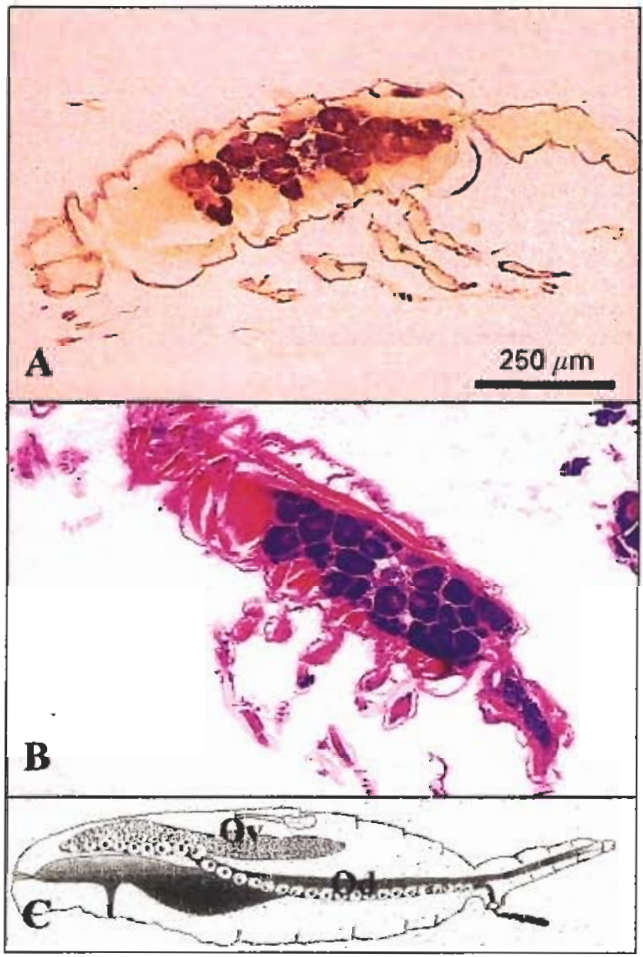

Fig. 1. Slides of a female Paracartia grani treated by in situ hybridization with Smart 2 probe $(A)$, and treated for conventional histology (Hemalum Eosin) (B) Schematic representation of a female copepod reproductive system $(\mathrm{C})$ with the germinal site of ovary (ov) and oviduct (od). On each figure, the anterior part of the copepod is on the left.

was detected (brown staining) in copepodid and adult females and located in the ovary (Fig. 1A, B, C). $M$. refringens was never detected in male copepods. The maximum prevalences of the parasite were $26 \%,(n=85)$ in copepodid females and $23 \%$ $(n=66)$ in adult females in August.

\section{Experimental transmission of Marteilia refringens}

Trial 1. After 7 days of cohabitation with infected flat oysters as described above, females of P. grani were infected by $M$. refringens with a prevalence of $3 \%(n=65)$. During the experiment, the prevalence ranged from $1.5(n=65)$ to $3 \%(n=33$, Table 2$)$ depending on the day of experiment (Table 2). Oysters and both male and female copepods from the controls remained uninfected during the experiment.

Trial 2. After 72 days of cohabitation with copepods sampled in the claire pond, the 90 flat oysters from the trial remained uninfected when analysed by in situ hybridization.

\section{DISCUSSION}

Marteilia refringens belongs to the phylum Paramyxea, which contains protistan parasites, infectious for marine invertebrates (Desportes \& Perkins, 1990 ;
Berthe et al. 2000). Paramyxean parasites are characterized by the formation of spores consisting of several cells enclosed inside one another, which result from internal cleavage within a stem cell. In the phylum Paramyxea, the species $M$. refringens in Europe and $M$. sydneyi, a parasite of Crassostrea glomerata (Saccostrea commercialis) in Australia (Perkins \& Wolf, 1976; Adlard \& Ernst, 1995) have been extensively studied but their life-cycle has remained uncharacterized.

As an approach to identifying potential host species participating in the transmission of $M$. refringens, we performed an exhaustive screening of the fauna of claire pond. Using PCR amplification of $M$. refringens DNA, we distinguished 4 groups of species: species where the parasite DNA was never, occasionally, or consistently amplified, as well as species where DNA amplification had not been obtained (even using universal primers). The distinction between these 4 groups allowed species presenting consistent detection of the parasite to be selected as the most probable candidates as $M$. refringens hosts. To draw conclusions on the status of a species as a host of $M$. refringens, several parameters have to be taken into account, such as the number of individuals sampled, the number of analyses performed, possible DNA amplification, and the presence of the parasite. For example, a limited number of individuals showing poor DNA amplification and no detection of the parasite does not allow a decision on the status (potential host or not) of the species.

The first limiting factor can be seen in the number of individuals sampled. This number mainly depends on the abundance of the species in the claire biotope and on the sampling strategy. As a consequence, it was difficult to decide on the status of scarce species such as Anguilla anguilla, platyhelminth species, Amphipholis squamata, Chlamys varia, Haliplanella luciae, Nephtys humbergii, chaetognath species, Pseudopolydora antennata, Doris verrucosa, Eulalia veridis, Cerastoderma edule, Ephydridae, Facellina coronata, Polydora ciliata. For these species, additional efforts should be made on the sampling frequency in order to increase the number of animals to be analysed. Nevertheless, if these species were infected by $M$, refringens, one can assume that the naturally low abundance of animals should be balanced by a higher parasite prevalence and infection level, therefore allowing the detection of $M$. refringens in the course of this study.

A second limiting factor is the number of analyses performed. For small size species (especially species from the meiofauna and zooplanktonic species), DNA extraction was realised on a pool of individuals. This could result in a dilution of the targeted DNA (i.e. $M$. refringens $\mathrm{DNA}$ ) and, possibly induce an underestimate of the parasite presence. As an example, in the case of Harpacticoïd copepods, pooling reduced 862 sampled individuals into 17 
Table 2. Results of the experimental transmission of Marteilia refringens from infected oysters to Paracartia grani

(Results of the experimental transmission of the parasite $M$. refringens between infected flat oysters and uninfected copepods. Prevalence of the parasite obtained by in situ hybridization on female copepods from the trail and the control (with the number of infected animals/the total number of females analysed). Disappearance of copepod was noted in the control on the 17 th and 25 th days of experiment.)

\begin{tabular}{|c|c|c|}
\hline $\begin{array}{l}\text { Time of exposure of } \\
\text { copepods to flat oysters } \\
\text { (day) }\end{array}$ & $\begin{array}{l}\text { Prevalence of } \\
M \text {. refringens } \\
\text { in copepods } \\
\text { from the control }\end{array}$ & $\begin{array}{l}\text { Prevalence of } \\
M . \text { refringens } \\
\text { in copepods } \\
\text { from the trial }\end{array}$ \\
\hline o (beginning of the experiment) & $0 \%(0 / 60)$ & $0 \%(0 / 60)$ \\
\hline 3 & $0 \%(0 / 44)$ & $0 \%(0 / 30)$ \\
\hline 7 & $0 \%(0 / 41)$ & $3 \%(2 / 65)$ \\
\hline 10 & $0 \%(0 / 17)$ & $1.5 \%(1 / 65)$ \\
\hline 17 & No copepod & $3 \%(1 / 33)$ \\
\hline 25 & No copepod & $0 \%(0 / 10)$ \\
\hline
\end{tabular}

performed analyses. On the other hand, reducing 285 individuals of $P$. grani to 8 analyses yielded 5 positive PCR results.

The third limitation encountered during this study, came from the absence or the low rate of DNA amplification during PCR when performed with universal primers. The absence of DNA amplification could be explained by the presence of inhibitory factors contained in the shell of crustaceans or molluses (Wilson, 1997; Le Roux et al. 1999). For example, shells of the shrimp Palaemon serratus were removed during this study, and led to a substantial improvement of the PCR reaction. However, shells of small crustaceans (Corophium volutator, Idothea chelipes), insects (Ephydridae) or molluscs (Abra segmentum, Hydrobia ulvae) could not be removed because of their small size, and they probably inhibited PCR amplification. For some species such as Hediste diversicolor, and Carcinus maenas the low rate of DNA amplification probably resulted from DNA degradation. In future studies, the time between sampling and sample preservation (which could last for $3 \mathrm{~h}$ due to the sorting of species) would have to be shortened to avoid DNA degradation. Similarly, alternative DNA extraction methods would have to be tested (Ferraris \& Palumbi, 1996).

Finally, the absence of detection of $M$. refringens can be seen as a failure of the overall strategy (sampling and screening). When taking into account the different factors cited above, most of the species included in this study cannot be firmly excluded from the hypothetical life-cycle. In contrast, the consistent detection of the parasite obtained in $P$. grani and $C$. pedunculatus strongly supported the hypothesis of their involvement in $M$. refringens lifecycle.

In order to discriminate between true parasitism and presence of $M$. refringens in the digestive tract or on the body surface, in situ hybridization was performed to localize the parasite in tissue sections. In situ hybridization experiments demonstrated presence of $M$. refringens in the ovary of $P$. grani. The ovarian tissue was frequently observed to be overwhelmed by $M$. refringens in the form of large numbers of small cells within ovocytes. Observed stages of $M$. refringens in $P$. grani, appeared to be morphologically different from the known stages observed in oyster digestive gland, although further transmission electron microscopy studies are obviously needed to characterize these developmental stages. The ovarian location of $M$, refringens may be surprising. However, other paramyxean parasites are known to target gonads of marine invertebrates: Marteilioides chungmuensis in Crassostrea gigas (Comps, Park \& Desportes, 1986) and Paramarteilia orchestiae in Orchestia gammarellus (GinsburgerVogel \& Desportes, 1979). The ovary appears during the moult of the first copepodid stage and keeps developing until the sexually mature adult stage (Schram, 1986). Infestation of the ovaries of some copepods has already been described in the case of microsporidian parasites (Andreadis, 1988; Micieli, Garcia \& Becnel, 2000) and infection of ovarian tissues does not seem to impede seriously normal metabolic processes (Andreadis, 1988).

Involvement of $P$. grani in the life-cycle of $M$. refringens seems consistent with both the ecology of this copepod and the epidemiology of the disease. Paracartia grani is mainly observed in bays and estuaries during spring and summer season (Alcaraz, 1983 ; Rodiguez \& Jimenez, 1990; Rodriguez, Guerrero \& Bautista, 1995; Guerrero \& Rodiguez, 1998) as it is the case in the claire ponds where it may represent $100 \%$ of the total copepod abundance. The seasonal cycle of $M$. refringens appears to match the life-cycle of $P$. grani, as it was shown that transmission occurs during summer (Grizel \& Tigé, 1977; Grizel, 1985). During winter, sporangia 
primordia of $M$. refringens observed in flat oysters do not develop. In spring, increase of water temperature fosters $M$. refringens development (Balouet, 1979; Berthe et al. 1998). Similarly, P. grani is absent from the water during winter (Rodriguez \& Jimenez, 1990; Rodriguez et al. 1995; Guerrero \& Rodriguez, 1998) to reappear in spring from resting benthic eggs. These eggs could play a role in overwintering of the parasite as reservoir for the parasite which will be investigated in future studies.

The geographical range of $P$. grani also matches $M$. refringens distribution. In Europe, marteiliosis has been reported to be restricted to north-western Brittany, the Bay of Biscay and the Mediterranean Sea, including the Atlantic coasts of Spain and the Adriatic coasts of Italy and Croatia. Paracartia grani is a warm temperate species orginating from the tropical and temperate Atlantic coast. It is a calanoid copepod typical of coastal, semi-confined ecosystems, conditioned by instability of both physical parameters (temperature and salinity) and biological conditions (quality and quantity of available food). This species is often observed in the vicinity of oyster beds (Gallo, 1981) and has been observed within the geographical range of the disease; in estuaries or bays where the parasite has been reported (Lubet, 1953; Paulmier, 1965, 1969; Alcaraz, 1983; Elbée (D’) \& Castel, 1995; SiokouFrangou et al. 1997; Razouls \& Bovée, 1999).

Determination of the role of P. grani in the lifecycle of $M$. refringens requires further experimental validation. Transmission of $M$. refringens from flat oysters to copepods was proved to be effective and rapid, as it was detected after 7 days of exposure to infected oysters. However, the prevalence of $M$. refringens in $P$. grani obtained by the experimental transmission was low. This could be due to a weak inoculum of parasites since the source of $M$. refringens consisted of oysters previously maintained at $12{ }^{\circ} \mathrm{C}$ and placed in experimental aquaria. They experienced a sharp increase of water temperature, which induced a synchronous release of sporangia in the faeces (Berthe et al. 1998). Consequently, the experimental design may have led to a unique flash of parasites, while a continuous release of parasite sporangia may occur under natural conditions. We therefore cannot assume that experimental conditions were optimal for transmission of the parasite from oysters to copepods.

No transmission of $M$. refringens was observed from copepods to oysters in our experiments. This also could result from non-optimal experimental conditions. The source of parasite may have been too weak to enable transmission. Presence of $M$. refringens in females of $P$. grani sampled in the summer 2000 was rare and the prevalence was low (less than $12 \%$ ). In 2000 , both copepods and oysters from the claire pond exhibited low prevalence of $M$. refringens as compared with the previous year where prevalence in adult copepods and oysters was respectively, $26 \%$ and $87 \%$.

The absence of parasite transmission in trial 2 could also reflect the involvement of a third species in the life-cycle of $M$. refringens. When considering this hypothesis, a candidate was $C$. pedunculatus in which the parasite was recurrently detected. In situ hybridization performed on 70 individuals never demonstrated $M$. refringens in tissues of $C$. pedunculatus. Consequently, detection of the parasite by PCR could be attributed to phoresy or ingestion of sporangia, infected copepods, or free-living stages of $M$. refringens because cnidarians are non-selective feeders (Van Praët, 1985). Among the 273 PCRs performed, 45 out of $190(23 \%)$ were positive when C. pedunculatus was sampled on oysters while 3 out of $83(4 \%)$ were positive when sampled on the sediment of the claire pond (data not shown). Thus, detection of the parasite DNA in C. pedunculatus seems to be correlated with the geographical distance from $M$. refringens-infected oysters. However, considering recurrent detection of the parasite, we can not exclude that $C$. pedunculatus may play a role in the $M$. refringens life-cycle, for example, in allowing capacitation or maturation of the parasite within the digestive cavity of this species. Future transmission experiments would have to investigate the role of this species in the $M$. refringens life-cycle.

From a more general point of view, the case of the cnidarian C. pedunculatus illustrates the confinement situation of claire ponds. In this ecosystem, species leading to occasional detection of $M$. refringens are numerous and it is difficult to discriminate accidental carriers from inconspicuous hosts. In the claire, $M$. refringens is present in oysters and copepods, as well as in sporangia released within oyster faeces. Other stages of $M$. refingens may exist, as free-living stages or within copepod eggs. $M$. refringens may be part of the food web of the claire pond, directly or indirectly. Considering the size of $M$. refringens sporangia ranging from 9 to $19 \mu \mathrm{m}$ (Grizel et al. 1974; Perkins $\left.\& W_{\text {olf }}, 1976\right)$, they could potentially be ingested by various pond microphageous species, including decapod larvae, copepods (cyclopoids, Camuella perplexa and Euterpina acutifrons), and ostracods (Dussart \& Defaye, 1995; Vannier, Abe \& Ikuta, 1998). The parasite could also be present within the digestive tract of annelid Streblospio spp., as they feed at the water interface upon suspended, resuspended and deposited material where the parasite can be present (Dauer, Maybury \& Ewing, 1981). Nemertean (Lineus spp.) or fish, Pomatochistus sp, may ingest not only free-living stages but also infected copepods. Phoresy of the parasite on the body surface may also explain occasional detection of the parasite. Basically, as $M$. refringens may be present on the sediment (at least as sporangia within oyster faeces) and in the water column, transport is conceivable by any benthic or pelagic species. If 
experimental transmissions from $P$. grani to $O$. edulis recurrently fail, these species will have to be studied further as potential host of $M$. refringens.

In conclusion, we demonstrated in the course of this study, that at least 2 species are involved in the life-cycle of $M$. refringens: $O$. edulis and $P$. grani. Transmission experiments between $O$. edulis and $P$. grani were successful, demonstrating that the 2 species are contiguous in the life-cycle of the parasite. First attempts of reverse transmission failed. Design of this experiment should be improved by enhancing the inoculum of $M$. refringens. This could be achieved by improving transmission rate from oysters to copepods reared in the laboratory or relying on better environmental conditions to increase naturally prevalence in copepods populations.

We are grateful for the contributions of S. Bodin, B. Chollet and the staff of the "Centre Régional d'Expérimentation et d'Application Aquacole' for their technical assistance. Authors would like to thank M-C. Sajus, M. Lucas and E. Morin for their involvement during the screening of the fauna and M. Audemard for adding her English touch. This study was supported by the European Community funding under the FAIR programme, project MARS (FAIR CT/PL97-3640).

\section{REFERENCES}

ADIAARD, R. D. \& ERNST, 1. (1995). Extended range of the oyster pathogen Marteilia sydneyi. Bulletin of the European Association of Fish Pathologists 15, 119-121

AICARAZ, M. (1983). Coexistence and segregation of congeneric pelagic Copepods, spatial distribution of the Acartia complex in the ria of Vigo (NW Spain). Fournal of Plankton Research 5, 891--900.

alderman, D. J. (1979). Epizootiology of Marteilia refringens in Europe. Marine Fishery Review 41, $67-69$.

ANDREADIs, T. G. (1988). Comparative susceptibility of the copepod Acanthocyclops vernalis to a Microsporidian parasite, Amblyospora connecticus, from the mosquito Aedes cantator. Fournal of Invertebrate Pathology 52, 73-77.

audemard, C., Barnaud, A., Collins, C. M., Le roux, F., Souriau, P.-G., colstal, C., Blachier, P. \& Berthe, F. C. J. (2001). Claire ponds as an experimental model for Marteilia refringens life-cycle studies: new perspectives. Fournal of Experimental Marine Biology and Ecology 257, 87-108.

BALOUET, G. (1979), Marteilia refringens - considerations of the life-cycle and development of Aber disease in Ostrea edulis. Marine Fishery Review 41, 64-66.

balouet, g., cahour, A. \& chastel, c. (1979 a). Epidémiologie de la maladie de la glande digestive de l'huître plate: hypothèse sur le cycle de Marteilia refringens. Haliotis 8, 323-326.

Baloust, G., Chastll, c., Cahour, A., Quillard, A. \& PODER, M. (1979 b). Etude épidémiologique et pathologique de la maladie de l'huître plate en Bretagne. Sciences et Pêche, Bulletin de l'Institut des Pêches maritimes 289, 13-22.

Berthe, F. C. J., PERnas, M., Zerabib, M., hafFner, P. H., THÉbALI,T, A. \& FIGUERAS, A. J. (I998). Experimental transmission of Marteilia refringens with special consideration of its life-cycle. Diseases of Aquatic Organisms 34, 135-144.

BERTHE, F. C. J., LE ROL'X, F., PLyRETAIl.LADE, E., PEYRET, P., ROdRiguez, D., GOUY, M. \& VIVAREs, C. P. (2000). Phylogenetic analysis of the small unit ribosomal RNA of Marteilia refringens validates the existence of the phylum Paramyxea (Desportes and Perkins, 1990). Fournal of Enkaryotic Microbiology 47, 288-293.

COMPS, M., PARK, M. S. \& DEsportes, M. S. (1986). Eitude ultrastructurale de Marteilioides chungmmensis n.g., parasite des ovocytes de l'huitre Crassostrea gigas Th. Protistologica 22, 279-285.

DaUer, D. M., MaYbury, c. A. \& EWING, R. M. (1981). Feeding behavior and general ecology of several Spionid Polychaetes from the Chesapeake bay. Fournal of Experimental Marine Biology and Ecology 54, 21-38. DESPORTES, I. \& PLRKINS, F. O. (1990). Phylum

Paramyxea. In Handbook of Protoctista (ed. Margulis, L., Corliss, J. O., Melkonian, M. \& Chapman, D. J.), pp. 30-35. Jones and Bartlett Publishing Corporation, Boston.

Dussart, B. H. \& DFFaye, D. (1995). Copepoda: introduction to the Copepoda. In Guides to the Identification of the Macroinvertebrates of the Continental Waters of the World, no. 7 (ed. Dumont, H. J. F.), pp. 43-52. SPB Academic Publishing, The Hague.

EL BÉ:E (D'), J. \& CASTR:, J. (1995). Evolution spatiotemporelle du zooplancton dans le bassin d'Arcachon: le rôle des variables de milieu. Cahiers de Biologie Marime 36, 33-45.

Ferrairis, J. D. \& Pallimi, s. R. (1996). Molecular Zoology: Advances, Strategies and Protocols. John Wiley and Sons, New York, USA.

figueras, A. J. \& Montes, J. (1988). Aber disease of edible oysters caused by Marteilia refringens. American Fisheries Society Special Publication 18, $38-46$.

Gallo, J.-M. (1981). Les copépodes pélagiques de la Rochelle. Annales de la Société des Sciences Naturelles de la Charente-Maritime 6, 847-850.

GiNSBLrger-vogeL, T. \& Desportes, I. (1979). Etude ultrastructurale de la sporulation de Paramarteilia orchestiae gen. n. sp.n. parasite de l'amphipode Orchestia gammarellus. Marime Fishery Review 41, $3-7$.

GRIZFI, H. (1985). Etude des récentes épizooties de l'huître plate Ostrea edulis Linné et de leur impact sur l'ostréiculture bretonne. Ph.D. thesis, University of Science, Montpellier.

grizel, h., COMPS, M., bONAMi, J. R., COUSSERANS, F, Duthoit, J. L. \& LI PEnnic, x. A. (1974). Recherche sur l'agent de la maladie de la glande digestive de Ostrea edulis Linné. Sciences et Pêche Bulletin de l'Institut des Pêches Maritimes 240, 7-30.

GRIZEL, H. \& TIGÉ, G. (1977). Observations sur le cycle de Marteilia refringens. Haliotis $\mathbf{8}, 327-330$.

GUTRRFro, F. \& Rodriguez, v. (1998). Existence and significance of Acartio grami resting eggs (Copepoda: Calanoida) in sediments of a coastal station in the Alboran Sea (SE Spain). Fonrnal of Plankton Research 20, 305-314. 
KORRINGA, P. (1976). Farming the cupped oysters of the genus Crassostrea. A multidisciplinary treatise.

Developments in Aquaculture and Fisheries Science, 2 , Elsevier Scientific Publication Compilation, Amsterdam

LE ROUX, F., AUDEMARD, C., BARNAUD, A., GOUY, M. \& BERTHE, F. C. J. (1999). Specifie molecular probes as potential tools for the detection of Marteilia refringens. Marine Biotechnology 1, 588--597.

L.LSTLR, R. J. G. (1986). Field and laboratory observations on the oyster parasite Marteilia sydneyi. In Parasite Lives (ed. Cremin, M., Dobson, C. \& Moorhouse, D. E.), pp. 33-40. University of Queensland Press, Brisbane.

I.LAET, P. (1953). Variations saisonnières du zooplancton du bassin d'Arcachon. Bulletin de la société zoologique de France 78, $204-216$.

Mialhe, E., Bachere, E., BOllo, v., CADORET, J. P., saraiva, J., Carrera, l., rousseau, (., Cedeno, v., CAIDERON, J. \& COLWELl, R. R. (1995). Future of biotechnology-based control of disease in marine invertebrates. Molecular Marine Biology and Biotechnology 4, 275-283.

MiCieli, M. V., GARCLA, J. J. \& BeCNEL, J. J. (2000).

Horizontal transmission of Amblyospora albifasciati Garcia and Becnel, 1994 (Microsporidia:

Amblyosporidae), to a copepod intermediate host and the neotropical mosquito, Aedes albifasciatus (Macquart, 1837). Fournal of Invertebrate Pathology $75,76-83$

19: MONTALDOUin, $\mathrm{x}$. \& SAURIAU, P-G. (2000). Contribution to a synopsis of marine species richness in the 'Pertuis Charentais Sea' with new insight in soft-bottom macrofauna of the Marennes-Oléron Bay. Cahiers de Biologie Marine 41, 181-222.

PaUlailer, G. (1965). Le microplancton de la rivière d'Auray. Revne des Travanx de l'Institut des Pêches Maritimes 29, 211-223.

PACIMIER, G. (1969). Le microplancton des rivières de
Moralaix et de la Penzé. Revue des Travanx de l'Institut des Pêches Maritimes 33, 311-332.

PFRKINS, F. O. \& WOLF, P. H. (1976). Fine structure of Martcilia sydneyi sp. n. - Haplosporidian pathogen of Australian oysters. Fournal of Parasitology 62, $528-538$.

RAzouls, C \& DE BOVÉE, F. (1999), Diversité et répartition géographique chez les Copépodes planctoniques marins. http://www.obsanyuls.fr/ Copepodes/RAZOULSI.htm

RFYMond, H. (1991). Dynamique de la chaine hétérotrophe benthique des marais maritimes en période estivale et son impact sur les productions aquacoles de carnivores: Penaeus japonicus, un modele d'étude. Ph.D. thesis, University of Paris Vl.

RODIRIGUEZ, v., GUiririrRo, F. \& BAUTISTA, B. (1995). Egg production of individual Copepods of Acartia grani Sars from coastal waters: seasonal and diel variability. Fournal of Plankton Research 17, 2233-2250.

RodriguFz, v. \& Jimisnfz, F. (1990). Co-existence of congeneric species of Acartia (Copepoda; Calanoida): sexual dimorphism and ecological niche in Acartia grani. Fournal of Plankton Research 12, 497-511. schrai, F. R. (1986). Crustacea. Oxford University Press, New York, USA

SIOKOU-FrangOU, I., PAPATHANASSIOU, E, LliplRETRE, A. \& rRONTIER, s. (1997). Zooplankton assemblages and influence of environmental parameters on them in a Vediterranean coastal area. Fonrnal of Plankton Research 20, 847-870.

VANNIER, J., ABE, K. \& IKUTA, K. (1998). Feeding in myodocopid ostracods: functional morphology and laboratory observations from videos. Marine Biology 132, 391-408.

VAN PRAËr, M. (1985). Nutrition of sea anemones. Advances in Marme Biology 22, 65-99

WII.SON, I. G. (1997). Inhibition and facilitation of nucleic acid amplification. Applied Emoironmental Microbiology 63, 3741-3751. 